\title{
A Study of the Relationship among Brand Experiences, Self-Concept Congruence, Customer Satisfaction, and Brand Preference
}

\author{
Yi-Ching Tsai \\ Shih Chien University \\ E-Mail: proworld@mail.kh.usc.edu.tw \\ Hui-Chen Chang \\ National Taipei University \\ E-Mail: cjenny@gm.ntpu.edu.tw \\ Kung-Chung Ho \\ National Taipei University \\ E-Mail: river10911@msn.com
}

\begin{abstract}
To meet the expectation of customers during experience era, it is important to understand their perceptions of different brands. To achieve this, this study aimed to investigate the relationship among brand experiences, self-concept congruence, customer satisfaction, and brand preference. This study used Tablet PC users as the research objects and collected empirical data through online questionnaires. Structural Equation Model (SEM) was used to validate models, and hierarchical regression was used to test the hypothesis. The results of this study showed that brand experience has a significant positive effect on brand preference, brand experience has a significant positive effect on customer satisfaction, and self-concept congruence has a positive effect on brand preference. In addition, self-concept congruence has positive effect on customer satisfaction and brand preferences. These results show that through a comprehensive brand experience, companies could enhance brand preferences and purchase intentions of customers.
\end{abstract}

${ }^{*}$ Correspondence Author 
Keywords: Brand Experiences, Self-Concept Congruence, Customer Satisfaction, Brand Preference

\section{INTRODUCTION}

The economy of human society is changing from commodity and service economy to experience economy. Morrison and Crane (2007) showed in their research that when consumers are purchasing products and services, they no longer focus on "purchase behavior" alone. Therefore, marketers must integrate other marketing elements, such as relationship management (Berry, 1983) and value creation (Ravald \& GrÖnroos, 1996), and they must provide consumers with a purchase process experience (Pine II \& Gilmore, 1998; Schmitt, 1999).

To meet the expectations of consumers in this experience economy era, the key is to understand how consumers experience brand, including any experience about the brand given by all mean to the customers, such as direct use of the product, receiving flyers of the brand, or watching a TV commercial of the brand; notably, more industries and organizations have adopted experience marketing measures to develop new products, communicate with customers, improve sales relationships, select venture partners, design a retail environment, and establish an Internet business. It is clear that more and more marketers have transferred away from traditional marketing (features-and-benefits) to customer experience creation (Schmitt, 1999). Therefore, in response to the increase in overall consumer demand, from the brand experience point of view, understanding the effect of brand experience on brand satisfaction and brand preference of consumers is a significant brand marketing strategy for business.

Schmitt (1999) first proposed the definition and measurement of brand experience. In 2009, Schmitt and two other scholars, Brakus and Zarantonello, amended the measurement scale and applied it to a research predicting consumer behavior (Zarantonello \& Schmitt, 2010). However, subsequent verification remains to be further substantiated. With the increasing symbolic demands of customers in self-expression of thoughts, feelings, or attitudes, many scholars have started to study brand image, personality, and relationships with consumers (Grohmann, 2009). According to self-concept congruence, consumers define themselves through products with a particular personality to express, maintain, and strengthen their self-concept (Sirgy, 1982). Matzler, Faullant, Renzl, and Leiter (2005) considered that customers' satisfaction with their own performance (customer self-satisfaction) influences customer satisfaction in settings with high customer participation. Customers' expression of self-concept through products is a psychological process of 
participation. Therefore, more consistent self-concept congruence increases customer self-satisfaction. For a long time, consumer behavior studies have focused on the product itself and the symbolic meaning of consumers' through self-concept (Belk, 1988). Consumers will have a positive attitude toward the brand that could clearly depict or express the consumers' self-concept (Aaker, 1999). Thus, the link between brands and consumers is worthy of further exploration.

The emergence of the Tablet PC has changed people's lifestyle. According to the statistics of Gartner (2015), a world-leading information technology research and advisory company, the sales of Tablet PC in 2011 and 2012 generated 0.63 billion and 1.03 billion dollars, respectively, showing a rapid growth by $60 \%$. The future Tablet PC industry will become more competitive and intense. The application of marketing strategy to brand experience in the increasingly fierce, competitive Tablet PC market motivates us to study the effect of brand experience on consumer choices in Tablet PCs. At the same time, some scholars believe that self-concept congruence could help strengthen emotional brand attachments and reaction behaviors (Aaker, 1999; Grohmann, 2009). It is worth exploring that, whether brand preference directly comes from self-concept congruence, or it is the satisfaction of customers to the brand that brings brand preference, which is the second aim of this study. Therefore, the purpose of this study is to (1) explore the effect of brand experience on brand preference of customers, (2) discuss the effect on self-concept congruence on the relationship among brand experience, consumer satisfaction, and brand preference, and (3) explore the effect of customer satisfaction on the relationship among brand experience, self-concept congruence, and brand preference.

\section{LITERATURE REVIEW}

\section{Brand Experience}

Pine II and Gilmore (1998) first proposed the "Experience Marketing" concept in the Harvard Business Review. Later, Schmitt (1999) argued that mature products with similar competitive strategies have made it difficult to distinguish a product by function, efficiency, quality, and services. Through the integration of brand and experience, Brakus, Schmitt, and Zarantonello (2009) proposed brand experience and further analyzed and constructed a measure of the construct.

Consumers can have a lasting memory of the brand experience and develop trust, commitment, and preference for the brand (Ha \& Perks, 2005). A long-term maintenance of brand experience will affect the satisfaction of consumers with the 
brand. Petromilli and Michalczyk (1999) proposed that brand experience of consumers will be formed through different contacts with different brands. Concerning various scholars' viewpoints on experimental dimensions, Schmitt's (1999) experience marketing is the dominating business strategy today. Schmitt (1999) divided experience into five dimensions, sensory experience, emotional experience, intelligence experience, dynamic experience, and relationship experience.

Brand experience could be positive or negative, short-term or long-term, and it could have a positive effect on customer satisfaction, customer loyalty, and brand association (especially brand personality) (Zarantonello \& Schmitt, 2010). Brakus et al. (2009) and Oliver, Roland, and Sajeev (1997) believed that consumers will be exposed to many different brand-related stimulations and consequently transfer those stimulations to brand experiences in long-term memories. These brand-related stimulations are the main source of consumer reactions, which are subjective and internal; thus, Brakus et al. (2009) defined brand experience in terms of the subjective and internal reactions of consumers to a brand (sensory, emotional and cognitive) and behavioral responses. These reactions are produced from brand-related stimulations (design and recognition of the brand, packaging, messaging, and environment).

Brakus et al. (2009) integrated information from various fields of study to conceptualize brand experience. He suggested that construction and measurement of a brand experience differ from other brand-related concepts. He further divided the internal section of brand experience into four concepts: 1. sensory, consumer's sense of brand stimulations, bringing consumers' brand impression and memory; 2 . affective, the emotional connection between the consumer and a particular brand; 3 . behavior, creation of brand experience related to physical body, long-term behavior and lifestyle, including those obtained from interaction with brands; and 4. intellectual, interactions with the brand give consumers intellectual stimulations and ideas, inducing customers to think innovatively. This research focused on the four concepts of brand experience proposed by Brakus et al. (2009).

\section{Self-Concept Congruence}

For a long time, consumer behavior research has been concerned with the meaning of self-congruence given to the consumers while owning the products (Belk, 1988). Some previous researches assumed that self-concept is a multi-oriented concept that could be explained from the cognitive and emotional perspectives (e.g., Lazzari, Fioravanti, \& Gough, 1978). Many scholars also believe that self-concept could be divided into two forms, the "actual self" and the "ideal self". Actual self is based on 
how people see themselves, and the ideal self is based on the imagination and goals to which people aspire (Lazzari et al., 1978).

Self-concept congruence refers to the convergence of consumers' preference in their images and the brand's self-concept, as consumers do not make purchases based only on the utility of the products. Consumers purchase products also because the products offer symbolic value (Sirgy, 1982). Grubb and Grathwohl (1967) proposed an image congruency hypothesis, believing that during the purchase process, and while using of these symbolic products, consumers could define, maintain, and enhance self-concept. Therefore, they will prefer products with image that matches their self-concept.

Studies in the social psychology discovered that self-concept is a multi-dimensional concept. They found that the effect of self-concept congruence on consumer behavior could be further divided into actual self-concept congruence effect, ideal self-concept congruence effect, as well as specific self-concept effect (Belk, 1988). They further revealed that even if the product image did not match consumers' actual self, they would still purchase the product if the product image matched the ideal-self of the customer. Sirgy, Grewal, Mangleburg, Park, Chon, and Claiborne (1997) and Malär, Krohmer, Hoyer, and Nyffenegger (2011) pointed out that actual self and ideal self are two widely studied dimensions, and they have a lot of empirical supports. Quester, Karunaratna, and Goh (2000) believed that in the field of consumer behavior, a specific self-concept could be used to explain and predict consumer behavior, considering actual self and ideal self as the most important factors.

Aaker (1999) focused on the product and proposed that consumers prefer brands with self-congruence. He used empirical research to prove the influence of self-congruence on consumer's brand evaluation, namely he proposed that consumers whose personality matched the brand have a more initiative attitude compared to those whose personality does not fit the brand. On the other hand, consumers could purchase products with a similar brand personality to establish actual or ideal self-congruence. Self-concept congruence refers to consistency between consumer's self and brand personality or image (Aaker, 1999). Additionally, brand and self-concept congruence has been believed to strengthen the affective level, attitudes, behavior of consumers, and brands (Grohmann, 2009). From the literature review, this research uses self-concept congruence to discuss the match of self-concept congruence with brand personality, product image, and consumer's self-concept. Based on the above discussion, we posit that, 
$\mathrm{H}_{1}$ : Brand experience has a positive effect on the self-concept congruence

\section{Customer Satisfaction}

Consumer satisfaction is one of the important variables that influences repeat purchase behavior (Cronin \& Taylor, 1992). Better customer satisfaction could increase repeat purchases (Cardozo, 1965), increase profitability and market share of companies, and help companies achieve marketing and financial goals (Anderson, Fornell, \& Lehmann, 1994; Oliver, Roland, \& Sajeev, 1997). Oliver (1997) pointed out that the long stored memory of experience will affect consumer satisfaction and loyalty. As well, customer satisfaction will affect attitude and further influence consumer repurchase intentions (Oliver, 1980). Higher customer satisfaction will improve consumers' memory of the brand and increase consumer preference for the brand (Westbrook \& Oliver, 1991).

Since Oliver (1980) proposed the expectancy disconfirmation theory, subsequent studies on customer satisfaction had an opportunity to delve deeper. He pointed out that customer satisfaction is a response to customers' complex emotion while purchase experience relates to inconsistency of customer satisfaction and the direction or magnitude of the expectation. The expectancy disconfirmation concept comprises two processes, the first is formation of expectations, and the second is the comparison between expectation and business standards. For example, before a purchase, consumers will first form product expectations and then compare the actual perceived feelings with the original expectations of the product.

Consumer satisfaction can be viewed from the perspective of "characteristic" and "scope" and defined from the cognitive perspective and affective perspective. In terms of the scope, consumer satisfaction could be viewed as a specific transaction or as an accumulated perspective (Parasuraman, Zeithaml, \& Berry, 1994).

Using the "cognitive perspective" of customer satisfaction, Oliver (1980) pointed out that consumers will most likely compare their expectations with actual service, purchase, or consumption they received afterward. When generated emotions and expectations are disconfirmed, then a type of psychological state, which is customer satisfaction, will be generated. In other words, customer satisfaction is generated from expectancy-disconfirmation. Using the "affective perspective" of customer satisfaction, satisfaction is gradually produced through experience and evaluation, which is a mood evaluation (Bloemer \& Odekerken-Schroder, 2002).

When defining the characteristic of customer satisfaction, some theories also have a wider perspective. Oliver (1993) proposed that discussing customer satisfaction 
or dissatisfaction only from one perspective provides insufficient explanation. Therefore, it needs to be considered through multiple aspects, including the recognition and affective factors. Oliver (1993) explained customer satisfaction using the recognition and affective factors, with a success rate of $80 \%$.

Using scope to define the customer satisfaction point of view, Parasuraman et al. (1994) first proposed transaction-specific satisfaction and overall satisfaction. Anderson et al. (1994) summarized related past research perspectives, and proposed two different points of view of customer satisfaction, which are transaction-specific satisfaction and overall satisfaction.

Transaction-specific perspective refers to the satisfaction or dissatisfaction of customers as a direct judgment of their service experience after receiving service. This perspective refers to the satisfaction of the evaluation, experience, and reaction of a specific product, service contact, or transaction (Rust \& Oliver, 1994). Perspective regarding accumulation views customer satisfaction as the cumulative customer evaluation of the product or service, which is a collective overall evaluation (Hellier, Geursen, Carr, \& Rickard, 2003).

Taking these perspectives, this research uses a modified version of Brakus et al. (2009) and Oliver's (1980) perspectives to discuss customer satisfaction. From the literature review, we posit that,

$\mathrm{H}_{2}$ : Brand experience has a positive effect on customer satisfaction

$\mathrm{H}_{3}$ : Self-concept congruence has a positive effect on customer satisfaction

\section{Brand Preference}

Preference is a type of attitude performance, which directs purchase decisions. Keller (1993) pointed out that brand awareness affects the consumer's product evaluation and choice while brand preference plays an important role in customer selection of products. If consumers prefer a certain brand and purchase the product or service when exposed to other products of the same type, this represents brand preference (Hellier et al., 2003).

From a psychological point of view, consumer's preferences include three main factors: cognitive, affective, and behavior. Crites, Fabrigar, and Petty (1994) pointed out that preference of a person can be shown by attitude and tendency of behavior of the person. Preference is the basis of attitude research, and it is consistent with the ABC theory (Affective, Behavior, Cognitive Model; Lutz, 1991). McGuire (1970) defined preference as a concept that includes multi-dimensional constructs, cognitive, affective, and behavior. First, brand preference is formed based on brand awareness. 
Brand awareness reflects the recognition of differences in brands in the minds of the customers, that is, being cognizant of brand's capability (Aaker, 1996). Generally, consumers' awareness of a brand is formed from their life experiences with accumulated awareness of related products, which is the process of recalling a brand (Riding \& Cheema, 1991). Second, the key to forming brand preference is brand emotion. Brand emotion is the reaction of consumers to a certain product, for example, the preference, dislike, appreciation of the product quality, trademarks, packages, service, and reputation, among others. Therefore, brand emotions have irrational tendencies. In some cases, consumers ignore rational thinking and just pick their favorite objects, which is the true reaction to brand emotion. Third, brand preference performance is a behavioral tendency. Behavioral tendency refers to how consumers show their preference for a brand, for example, by purchasing a certain product or making a repeat purchase.

Differences in consumers' self-concepts lead to different purchase behaviors. A number of studies have shown that consumers are willing to choose products with a brand image that is consistent with their self-concepts to enhance their own self-concept (Sirgy, 1982; Grohmann, 2009). Consumers use products to not only develop their own self-concept, but also modify it through purchasing and using products.

Brand is also a designation, logo, symbol, image, design, or a combination of the above that is used to distinguish the products or services from competitor's products or services (Kotler, 1999). If the brand became the intermediary between consumers' self-realization and self-expression, the consumers would be more likely to accept the brand. Higher customer satisfaction would strengthen the memory of the brand and enhance brand preference. Thus, we posit that,

$\mathrm{H}_{4}$ : Customer satisfaction has a positive effect on brand preference.

$\mathrm{H}_{5}$ : Self-concept congruence has a positive effect on brand preference.

$\mathrm{H}_{6}$ : Brand experience has a positive effect on brand preference.

\section{METHOD}

\section{Research Framework}

This study used Brakus et al.'s (2009) model of brand experience as the foundation and, according to research results by Krohmer, DeMarchi, Baleckaitis, Lutterschmidt, and Mason (2011), added the consumer psychology of self-concept 
congruence, brand preference, and other constructs. Based on the literature review, this study established the research framework shown in Figure 1.

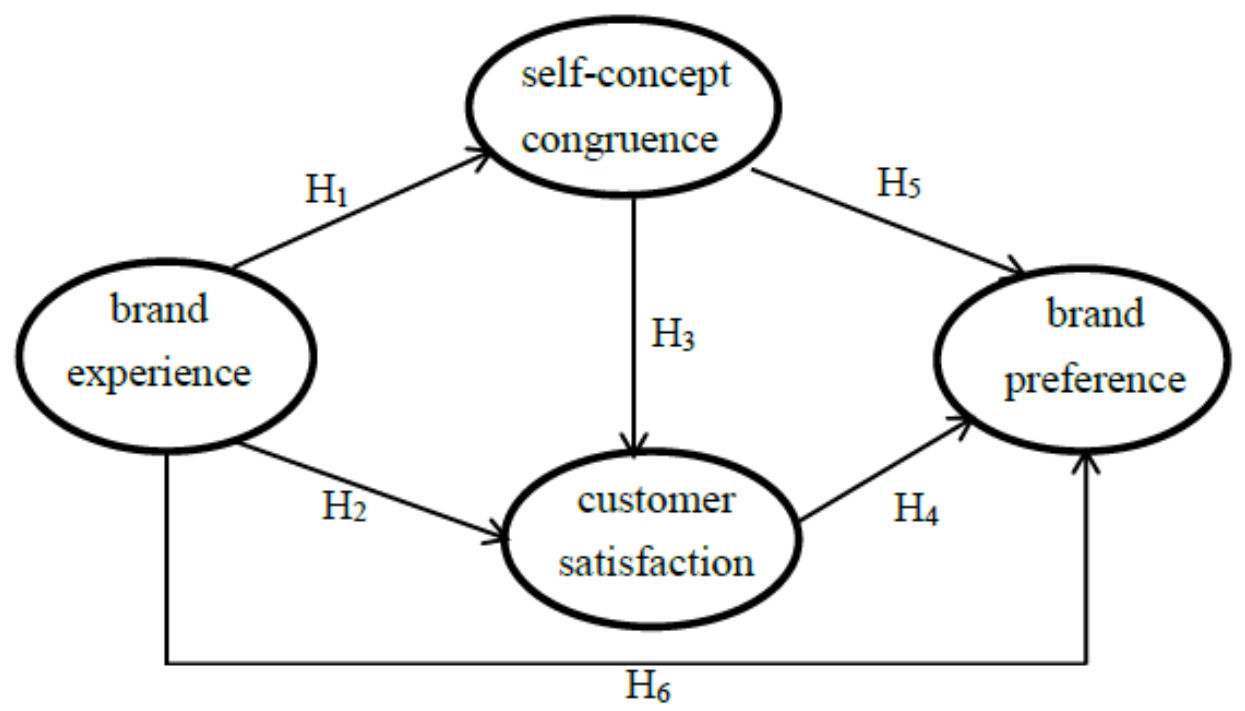

Figure 1 Research Framework

\section{Research Object and Sampling}

This study chose the Tablet PC industry in Taiwan as an example to discuss the experience and behavior between consumers and the Tablet PC brand. The respondents were Taiwanese consumers that use Tablet PCs. Internet questionnaires were used to collect the data and convenience and snowball sampling was used to recruit the participants. The Internet surveys were administered from April 2 to May 6 in 2012 through MySurvey Internet platform. Overall, 346 surveys were collected, out of which 313 were valid, reflecting an effective sample rate of $85.98 \%$.

\section{Variables and Measurement}

The measurement tools in this study were adopted from the research literature. The scale items were measured on a 5-point Likert scale using the following responses, "strongly disagree", "do not agree", "no opinion", "agree", and "strongly agree".

\section{- Brand Experience}

This study follows a theory of Brakus et al. (2009) in which brand experience is regarded as the subjective internal and behavioral reaction of consumers (sensory, emotional, and cognitive). These reactions are due to brand-related motivations (design and recognition of the brand, packaging, message, and environment). 
Consistent with Brakus et al.'s (2009) four dimensions related to brand experience, sensory, emotional, behavioral, and intelligent experience, we developed a 9-item brand experience scale.

\section{- Self-Concept Congruence}

This study measured self-concept congruence based on Krohmer et al.'s (2011) theory definitions of "actual self-congruence", i.e., the degree of similarity of the surveyor's perception of brand personality to themselves, and "ideal self-congruence", i.e., degree of similarity of surveyor's awareness of brand personality to their self-expectations. The actual self refers to how individuals see themselves while the ideal self refers to individuals' ideal image in themselves (Sirgy, 1982; Sirgy et al., 1997). Four items measure the self-concept variable.

\section{- Customer Satisfaction}

Oliver (1980) pointed out that customers will usually compare the actual products and services to their expectations. When they feel inconsistency, the psychological state of customer is customer satisfaction. Thus, consumer satisfaction develops when expectations are consistent with actual cognition (expectancy-disconfirmation). A modified version of Brakus et al. (2009) and Oliver's (1980) satisfaction scale was used to measure four items.

\section{- Brand Preference}

Hellier et al. (2003) believed that brand preference is the choice of a product or service of a certain brand made by customers when consumers face similar kind of products or service. This study used Hellier et al.'s (2003) measurement scale to propose two items.

\section{RESULTS}

\section{Analysis of Sample Structure}

The surveys were analyzed and classified into different sections. The demographic characteristics indicated that the majority of the respondents were male (66.5\%) and most were under 20 years old (19.2\%) and 21-25 years (55.0\%). Most respondents completed Bachelor (65.2\%) followed by Master and $\mathrm{PhD}(31.4 \%)$ degrees. The respondents were mainly salary workers $(63.3 \%)$ while the rest were students $(36.7 \%)$. The average yearly income was $\$ 20,000$ or lower for most 
individuals $(66.1 \%)$ followed by $\$ 20,001$ to $\$ 50,000(25.2 \%)$. Most of the respondents lived in Northern Taiwan (76.3\%), Central Taiwan (9.3\%), and in Southern Taiwan (12.8\%).

\section{Measurement Model}

Before testing the hypothesis, this study used LISREL 8.51 statistical software tools to conduct confirmatory factor analysis (CFA) and hierarchical confirmatory factor analysis (HCFA) to assess the reliability and validity of the model and the goodness of fit. Model fit indicators, $\chi 2=421.45$, $\mathrm{df}=146, \mathrm{AGFI}=0.82, \mathrm{SRMR}=0.077$, RMSEA $=0.083, \mathrm{CFI}=0.91$, were all within the accepted standards (Hair, Anderson, Tatham, \& Black, 1998).

Table 1 Reliability and Validity Statistics of Measurement

\begin{tabular}{lccccc}
\hline Construct & Item & $\lambda$ & CR & $\alpha$ & AVE \\
\hline Sensory Experience & BES1 & 0.87 & 0.87 & 0.87 & 0.77 \\
& BES2 & 0.88 & & & \\
\hline Affective Experience & BEA1 & 0.66 & 0.64 & 0.64 & 0.50 \\
& BEA2 & 0.72 & & & \\
\hline Behavioral Experience & BEB1 & 0.82 & 0.74 & 0.73 & 0.60 \\
& BEB2 & 0.71 & & & \\
\hline Intelligent Experience & BEI1 & 0.66 & 0.73 & 0.72 & 0.50 \\
& BEI2 & 0.75 & & & \\
& BEI3 & 0.65 & & & \\
\hline Customer Satisfaction & CS1 & 0.68 & 0.81 & 0.81 & 0.52 \\
& CS2 & 0.79 & & & \\
& CS3 & 0.76 & & & \\
& CS4 & 0.65 & & & \\
\hline Self-concept Congruence & SCC1 & 0.75 & 0.91 & 0.90 & 0.72 \\
& SCC2 & 0.87 & & & \\
& SCC3 & 0.92 & & & \\
\hline Brand Preference & SCC4 & 0.84 & & & \\
\hline & BP1 & 0.79 & 0.70 & 0.70 & 0.54 \\
& BP2 & 0.67 & & & \\
\hline
\end{tabular}


Regarding the reliability and validity of research measurement, as Table 1 indicates, excluding "affective experience", which has a Cronbach's $\alpha$ value of 0.64 , all Cronbach's $\alpha$ values ranged from 0.7 to 0.9 , indicating a good internal consistency (Nunnally, 1978). CR values were mostly over greater than 0.6 , demonstrating good composite reliability (Huang, 2004). This study measured the factor loadings $(\lambda)$ that ranged from 0.61 to 0.96 . Besides a small number of items with factor loadings smaller than 0.7 , the remaining were higher than 0.70 , showing the scale has good concurrent validity (Hair et al., 1998). The average variance extracted (AVE) was greater than Bagozzi and Yi's (1988) suggestion of 0.5, indicating that each measurement has good convergent validity. From Huang's (2004) point of view, the non-diagonal values in the correlation coefficient table are smaller than 0.95 . Fornell and Larcker (1981) suggested that AVE square root value of the individual constructs should be greater than the correlation coefficient of other constructs. In this study, as Table 2 shows, the non-diagonal values were less than 0.95 and smaller than the value of the square root of the AVE, indicating the measurement has good discriminant validity.

Table 2 Correlations and Discriminant Validity

\begin{tabular}{cccccccc} 
& BES & BEA & BEB & BEI & CS & SCC & BP \\
\hline BES & 0.87 & & & & & & \\
\hline BEA & 0.58 & 0.70 & & & & & \\
\cline { 3 - 7 } BEB & 0.59 & 0.77 & 0.77 & & & & \\
\hline BEI & 0.57 & 0.82 & 0.70 & 0.70 & & & \\
\hline CS & 0.65 & 0.43 & 0.69 & 0.51 & 0.72 & & \\
\hline SCC & 0.46 & 0.65 & 0.65 & 0.69 & 0.55 & 0.85 & \\
\hline BP & 0.60 & 0.43 & 0.67 & 0.53 & 0.86 & 0.59 & 0.73 \\
\hline
\end{tabular}

$\mathrm{BES}=$ sensory experience, $\mathrm{EA}=$ affective experience, $\mathrm{BEB}=$ behavior experience, $\mathrm{BEI}=$ intelligence experience, $\mathrm{CS}=$ customer satisfaction, $\mathrm{SCC}=$ self-concept congruence, $\mathrm{BP}=$ brand preference Diagonal values are $\sqrt{\mathrm{AVE}}$ values.

\section{Hypothesis Testing}

This study used structural equation modeling (SEM) to test the structure of the model of this study, and the results are shown in Figure 2 and Table 3. 
The model validation in Table 3 and standardized model path coefficients in Figure 2 reveal that brand experience positively affects brand preference, and also will simultaneously form brand preference through self-concept congruence or consumer satisfaction. In addition, brand experience positively influences brand preference through the self-concept congruence, resulting in customer satisfaction.

Brand experience has a direct effect of 0.23 and brand experience has a total indirect effect of 0.47 on brand preference. 1 . The path between brand experience $\rightarrow$ self-concept congruence $\rightarrow$ brand preference was $0.25(0.74 * 0.34)$. 2. The path between brand experience $\rightarrow$ self-concept congruence $\rightarrow$ customer satisfaction $\rightarrow$ brand preference path was $0.07(0.74 * 0.29 * 0.34) .3$. The path between brand experience $\rightarrow$ customer satisfaction $\rightarrow$ brand preference was $0.15(0.43 * 0.34)$. The total effect of brand experience on brand preference was $0.70(0.23+0.47)$. Table 4 summarizes the empirical results of all hypothesis in this study.

Table 3 Model Testing Results

\begin{tabular}{lccc}
\hline \multicolumn{1}{c}{ Path } & $\begin{array}{c}\text { Standardization } \\
\text { Path Coefficient }\end{array}$ & T-values & Probability \\
\hline brand experience $\rightarrow$ sensory experience & 0.70 & 10.43 & $p<0.001$ \\
\hline brand experience $\rightarrow$ affective experience & 0.86 & 10.46 & $p<0.001$ \\
\hline brand experience $\rightarrow$ behavior experience & 0.89 & 12.77 & $p<0.001$ \\
\hline brand experience $\rightarrow$ intelligence experience & 0.85 & 11.40 & $p<0.001$ \\
\hline brand experience $\rightarrow$ self-concept congruence & 0.74 & 12.18 & $p<0.001$ \\
\hline brand experience $\rightarrow$ customer satisfaction & 0.43 & 12.37 & $p<0.001$ \\
\hline brand experience $\rightarrow$ brand preference & 0.23 & 2.93 & $p<0.001$ \\
\hline self-concept congruence $\rightarrow$ customer satisfaction & 0.29 & 12.37 & $p<0.001$ \\
\hline self-concept congruence $\rightarrow$ brand preference & 0.34 & 12.37 & $p<0.001$ \\
\hline customer satisfaction $\rightarrow$ brand preference & 0.34 & 12.37 & $p<0.001$ \\
\hline
\end{tabular}


Table 4 Hypothesis Testing Results

\begin{tabular}{|c|c|c|}
\hline & Hypothesis & Results \\
\hline $\mathrm{H}_{1}$ & Brand experience has a positive effect on the self-concept congruence & Supported \\
\hline $\mathrm{H}_{2}$ & Brand experience has a positive effect on customer satisfaction & Supported \\
\hline $\mathrm{H}_{3}$ & Self-concept congruence has a positive effect on customer satisfaction & Supported \\
\hline $\mathrm{H}_{4}$ & Customer satisfaction has a positive effect on brand preference & Supported \\
\hline $\mathrm{H}_{5}$ & Self-concept congruence positive effect on brand preference & Supported \\
\hline $\mathrm{H}_{6}$ & Brand experience has a positive effect on brand preference & Supported \\
\hline
\end{tabular}

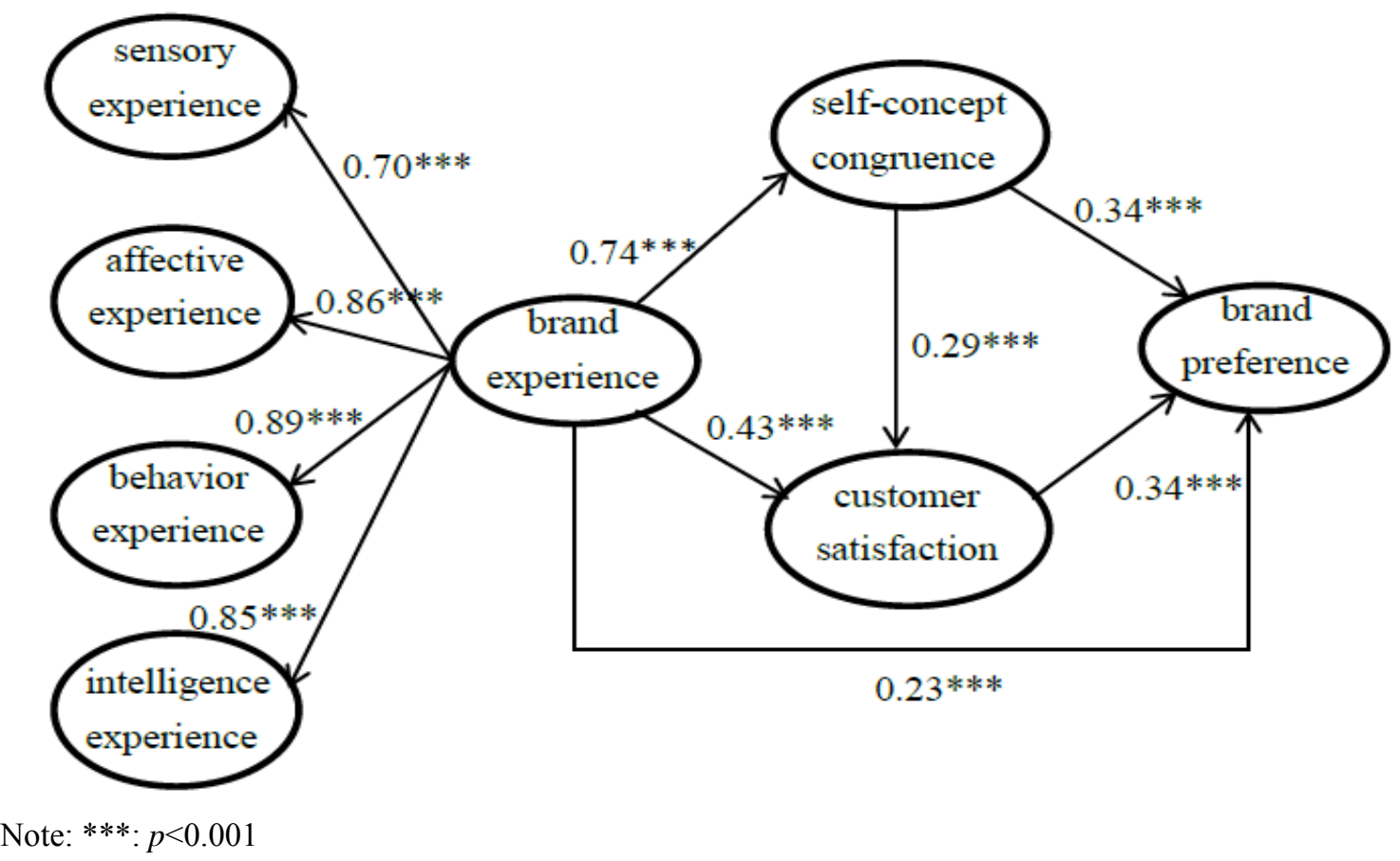

Figure 2 Model Path Coefficient

\section{CONCLUSION}

This study focused on tablet PC users. Structural equation modeling was used to verify the relationship among brand experience, self-concept congruence, customer satisfaction, and brand preference. This study has experimentally proved that Brakus et al.'s (2009) model of the brand experience is able to fully reflect customers' internal point of view of the brand, which can be constructed via the four dimensions 
of brand experience: sensory, feelings, behavior, and intelligence. In other words, businesses could understand the feelings of consumers towards brands through these four dimensions; thus, they can design and provide a full range of brand experiences to enhance consumer preferences.

Self-concept congruence has a positive effect on brand preference. If brand products or services could help consumers define, maintain, and promote self-concept; it will ultimately affect customers while they are choosing brands. A greater congruency between brands and self-concept increases satisfaction with and preference for a brand.

Evidence from this study also shows that brand experience does not affect customer satisfaction and brand preference only directly, but also indirectly through self-concept. Brand experience has a direct and positive effect on brand preference, which means the more experiences customers have with the brand, the greater preference of the brand they will develop. Thus, when the products or services of a particular brand match the self-concept of customers, then they will experience a higher preference and satisfaction. In other words, if brands could use designs, identification, packaging, messages, and environmental elements to enhance the match between consumers' self-concept and brand attributes, then they would be able to guide consumers to make purchase decisions in favor of the brand.

Companies should use "brand experience" as a marketing strategy tool to establish "brand-consumers" strategy. The results of this study showed that in the Tablet PC industry, consumers value behavioral experience beyond all other brand experiences, showing that if the Tablet PC industry wants to establish or maintain brand relationships with consumers in this information-blast environment, it should focus first on behavioral experience. Companies should focus on creating a behavior model and a lifestyle-related brand experience of customers as well as customer experiences with the brand. Therefore, if the supplier designs products, services, or operating software related to a customers' daily lifestyle, the supplier with enhance brand experience and consumers will continue to have an interactive experience with the brand.

On the other hand, consumers nowadays have begun to pay attention to factors such as emotion and self-presentation. For brand experience, affective experience and intelligence experience has also shown significant effect on customers in addition to the effect of behavioral experience in Tablet PC industry. In other words, when consumers are choosing Tablet PC brands, they will also be affected by emotion-related and brain-stimulating factors. From the results of this study, 
self-concept congruence has a positive effect on customer satisfaction and brand preference, according to the two approaches, cognition and emotion perspectives. This means that in addition to sensory, behavior, or intelligence enjoyment that consumers expect to obtain, they anticipate emotion and self-presentation benefits. In other words, affective level of experience is a key factor that cannot be ignored when customers make decisions. If business managers and marketing personnel want consumers to establish long-term preferences for their brands, they should spend more time and effort to create an affective experience for consumers.

\section{REFERENCES}

Aaker, D. A. (1996a). Measuring brand equity across products and markets. $\begin{array}{llll}\text { California Management } \quad \text { Review, } & \text { 38, }\end{array}$ http://dx.doi.org/10.2307/41165845

Aaker, J. L. (1999). The malleable self: The role of self-expression in persuasion. Journal of Marketing Research, 36(1), 45-57. http://dx.doi.org/10.2307/3151914

Anderson, E. W., Fornell, C., and Lehmann, D. R. (1994). Customer satisfaction, market share, and profitability: Findings from Sweden. Journal of Marketing, 58(3), 53-66. http://dx.doi.org/10.2307/1252310

Bagozzi, R. P. and Yi, Y. (1988). On the evaluation of structural equation models. Journal of the Academy of Marketing Science, 16(1), 74-94. http://dx.doi.org/10.1007/BF02723327

Belk, R. W. (1988). Possessions and the extended self. Journal of Consumer Research, 15(2), 139-68. http://dx.doi.org/10.1086/209154

Berry, L. L. (1983). Relationship Marketing, in Berry, L. L., Shostack, G. L., Upah, G. D., (Eds.) Emerging Perspectives on Service Marketing, Chicago, IL: American Marketing Association, 25-28.

Bloemer, J. and Odekerken-Schroder, G. (2002). Store satisfaction and store loyalty explained by customer and store-related factors. Journal of Consumer Satisfaction, Dissatisfaction and Complaining Behavior, 15, 68-80.

Brakus, J. J., Schmitt, B. H., and Zarantonello, L. (2009). Brand experience: What is it? How is it measured ? Does it affect loyalty? Journal of Marketing, 73, 52-68. http://dx.doi.org/10.1509/jmkg.73.3.52

Cardozo, R. N. (1965). An experimental study of customer effort, expectation, and satisfaction. Journal of Marketing Research, 2(3), 244-249. http://dx.doi.org/10.2307/3150182 
Crites, S.L., Jr., Fabrigar, L.R., and Petty, R. E. (1994). Measuring the affective and cognitive properties of attitudes: conceptual and methodological issues. Personality and Social Psychology Bulletin, 20, 619-634. http://dx.doi.org/10.1177/0146167294206001

Cronin, J. J. and Taylor, S. A. (1992). Measuring service extension. Journal of Marketing, 56(3), 55-68.

Fornell, C. and Larcker, D. F. (1981). Evaluating structural equation models with unobservable variables and measurement error. Journal of Marketing Research, 18(1), 39-50. http://dx.doi.org/10.2307/3151312

Gartner (2015). "Forecast: PCs, Ultramobiles and Mobile Phones, Worldwide, 2011-2018, 4Q14 Update" Retrieved from http://www.gartner.com/document/2945917.

Grohmann, B. (2009). Gender dimensions of brand personality. Journal of Marketing Research, 46(2), 105-119. http://dx.doi.org/10.1509/jmkr.46.1.105

Grubb, E. and Grathwohl, H. (1967). Consumer self-concept, symbolism and market behavior: A theoretical approach. Journal of Marketing, 31(4), 22-27. http://dx.doi.org/10.2307/1249461

Ha, Y. H. and Perks, H. (2005). Effects of consumer perceptions of brand experience on the web: Brand familiarity, satisfaction and brand trust. Journal of Consumer Behavior, 4(6),438-452. http://dx.doi.org/10.1002/cb.29

Hair, J. F., Anderson, R. E., Tatham, R. L., and Black, W. C. (1998). Multivariate Data Analysis (5th Ed.). Prentice Hall, Uppersaddle River, NJ.

Hellier, P. K., Geursen, G. M., Carr, R. A., and Rickard, J. A. (2003). Customer repurchase intention: A general structural equation model. European Journal of Marketing, 37(11), 1762-1800. http://dx.doi.org/10.1108/03090560310495456

Huang, F. M. (2004). Social Science Statistical Methodology : Structural Equation Modeling, Taipei: Wu-Nan Press.

Keller, K. L. (1993). Conceptualizing, measuring, and managing customer-based brand equity. Journal of Marketing Research, 57(1), 1-22. http://dx.doi.org/10.2307/1252054

Kotler, P. (1999). Marketing Management: An Asian Perspective. Singapore: Prentice Hall.

Krohmer, R.W., DeMarchi, G. A., Baleckaitis, D. D., Lutterschmidt, D., and Mason, R. T. (2011). Brain nuclei in actively courting red-sided garter snakes: A paradigm of neural trimorphism. Physiology \& Behavior, 102(5), 532-537. http://dx.doi.org/10.1016/j.physbeh.2010.12.022 
Lazzari, R., Fioravanti, M., and Gough, H. G. (1978). A new scale for the adjective check list based on self versus ideal-self discrepancies. Journal of Clinical Psychology, $34(2)$, $361-65$. http://dx.doi.org/10.1002/1097-4679(197804)34:2<361::AID-JCLP2270340218> 3.0.CO;2-6

Lutz, R. J. (1991). The Role of Attitude Theory in Marketing, in Handbook of Consumer Behavior, Prentice Hall, 4th ed., 317-339.

Malär, L., Krohmer, H., Hoyer, D. W., and Nyffenegger, B. (2011). Emotional brand attachment and brand personality: The relative importance of the actual and the ideal self. Journal of Marketing, 75, 35 -52.

Matzler, K., Faullant, R., Renzl, B., \& Leiter, V. (2005). The Relationship between Personality Traits (Extraversion and Neuroticism), Emotions and Customer Self-Satisfaction. Innovative Marketing, 1(2), 32-39.

McGuire, W. J. (1970). A vaccine for brainwash. Psychology Today, 3(February), 36-39, 63-64.

Morrison, S. and Crane, F. (2007). Building the service brand by creating and managing an emotional brand experience. Journal of Brand Management, 14(5), 410-421. http://dx.doi.org/10.1057/palgrave.bm.2550080

Nunnally, J. (1978). Psychometric Theory, 2nd ed. New York: McGraw-Hill.

Oliver, R. L. (1980). A cognitive model of the antecedents and consequences of satisfaction decisions. Journal of Marketing Research, 17(4), 460-69. http://dx.doi.org/10.2307/3150499

Oliver, R. L. (1993). Cognitive, affective, and attribute bases of the satisfaction response. Journal of Consumer Research, 20(3), 418-30. http://dx.doi.org/10.1086/209358

Oliver, R. L. (1997a). Satisfaction: A Behavioral Perspective on the Consumer. Boston: McGraw-Hill.

Oliver, R. L., Roland T. R., and Sajeev, V. (1997b). Customer delight: Foundations, findings, and managerial insight. Journal of Retailing, 73(3), 311-36. http://dx.doi.org/10.1016/S0022-4359(97)90021-X

Parasuraman, A., Zeithaml, V.A., and Berry, L.L. (1994). Reassessment of expectations as a comparison standard in measuring service quality: Implications for future research. Journal of Marketing, 58(1), 111-124.

Petromilli, M. and Michalczyk, D. (1999). Your most valuable asset. Marketing Health Service, 19, 4-9. 
Pine II, B. J. and Gilmore, J. H. (1998). Welcome to the experience economy. Harvard Business Review, July-August, 97.

Quester, P. G., Karunaratna, A., and Goh, L. K. (2000). Self-congruity and product evaluation: A cross-cultural study. Journal of Consumer Marketing, 17(6), 525-535. http://dx.doi.org/10.1108/07363760010349939

Ravald, A. and GrÖnroos, C. (1996). The value concept and relationship marketing. $\begin{array}{llll}\text { European Journal of } & \text { Marketing, }\end{array}$ http://dx.doi.org/10.1108/03090569610106626

Riding, R.J. and Cheema, I. (1991). Cognitive styles: An overview and integration. Educational Psychology, 11(3 \& 4$)$ : 193-215. http://dx.doi.org/10.1080/0144341910110301

Rust, R. T. and Oliver, R. L. (1994). Service Quality: Insights and managerial Implications from the Frontier, in Rust, R. T. and Oliver, R. L., Eds., Service Quality: New Directions in Theory and practice, Thousand oaks, CA: Sage Publications.

Schmitt, B. H. (1999). Experiential marketing: How to Get Customers to Sense,Feel, Think, Act,Relate to Your Company and Brands. New York: The Free Press.

Sirgy, M. J. (1982). Self-concept in consumer behavior: A critical review. Journal of Consumer Research, 9(3), 287-300. http://dx.doi.org/10.1086/208924

Sirgy, M. J., Grewal, D., Mangleburg, T. F., Park, Jae-ok, Chon, Kye-Sung, and Claiborne, C. B. (1997). Assessing the predictive validity of two methods of measuring self-image congruence. Journal of the Academy of Marketing Science, 25(3), 229-41. http://dx.doi.org/10.1177/0092070397253004

Westbrook, R. A. and Oliver, R. L. (1991). The dimensionality of consumption emotion patterns and consumer satisfaction. Journal of Consumer Research, 18(June), 84-91. http://dx.doi.org/10.1086/209243

Zarantonello, L. and Schmitt, B. H. (2010). Using the brand experience scale to profile consumers and predict consumer behavior. Journal of Brand Management, 17(February), 532-540. http://dx.doi.org/10.1057/bm.2010.4 
